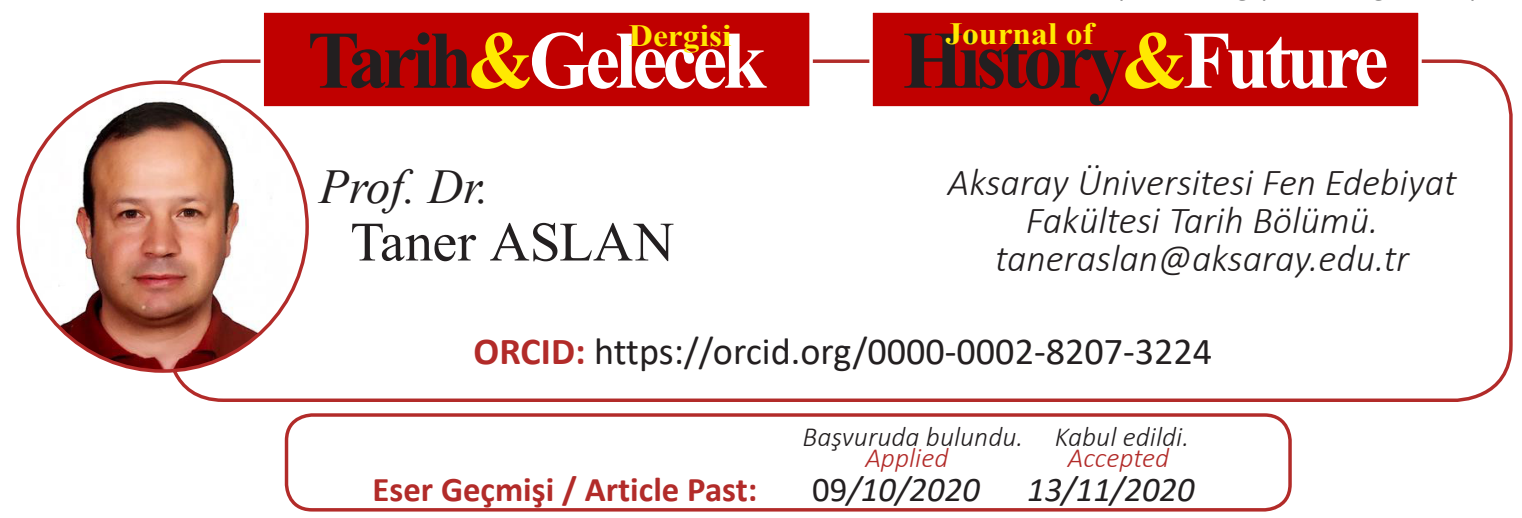

Araştırma Makalesi

DOI: http://dx.doi.org/10.21551/jhf.808214

Research Paper

Orjinal Makale / Orginal Paper

\title{
Milli Mücadele Sonrasında Milli Birlik ve Beraberliğin Tesisinde Gazetelerin Rolü: Milli Gaye Gazetesi Örneği
}

\section{The Role of Newspapers in the Provision of National Unity and Solidarity after the War of Independence: An Example of "Milli Gaye" (National Ideal) Newspaper}

Öz

Kurtuluş Savaşı'nın zaferle neticelenmesinden sonra, ülkemizin her köşesinin inkişafı için yeni bir mücadele hamlesi başlatılmıştır. Bu mücadelede matbuata önemli görevler düşmüştür. Hususiyetle, taşrada çıkan yerel matbuat, büyük öneme sahip olmuştur. Bu bağlamda, Bolu Vilayeti’nde 1922 tarihinde çıkan Milli Gaye Gazetesi, Türk Milleti’nin sa y ve gayretinde, ülkesinin tensik ve inşasında önemli rol oynamıştır. Bunun yanı sıra, Türk gençliğinin ilim irfan yolunda terakki etmesi için de büyük sarf etmiştir. 9 sayı çıkan gazetenin yayın politikası, Türk gençliğinin millî ve ahlakî gelişimini sağlamaktır. Gazetenin müdürü Süleyman Avni Bey’dir. Yazar kadrosu Bolu Sultanisi öğretmenlerinden oluşmaktadır. Gazetenin yerel bir gazete olması hasebiyle, yerel matbuatın kamuoyu oluşturmadaki etkisi ve gücünü ortaya koyması ile yerel tarih çalışmalarına verdiği katkısı, çalışmayı önemli hale getirmektedir.

Anahtar Kelimeler: Milli Gaye Gazetesi, Bolu, Eğitim, Milli Birlik, Milli Mücadele, Matbuat.

\section{Abstract}

After the victory of the War of Independence, Turkey initiated a new movement for the development of every corner of the country. The press played an essential role in this movement-specifically the local press in the rural was of great importance. In this regard, the "Milli Gaye Newspaper" (National Ideal) which was published in Bolu Province in 1922, had an important role in the efforts of the Turkish Nation, and the establishment of Turkey. Besides, it made excellent contributions to develop science and knowledge among Turkish youth. The paper was published in nine issues. The editorial policy of the newspaper was to ensure the national and moral development of the Turkish youth. Suleyman Avni Bey was the director of the newspaper. The editorial staff consisted of the teachers working at Bolu Sultani 
(high school). Since it was a local newspaper, its contributions to the local history studies made it essential to address due to revealing the impact and power of the local press on creating public opinion.

Key Words: Milli Gaye (National Ideal) Newspaper, Bolu, Education, National Unity, National Struggle, Printing.

\section{Giriş}

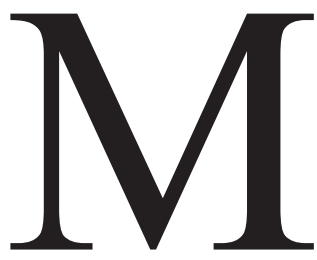

atbuat, milletin ilmî ve fennî, siyasî ve edebî nokta-i nazardan inkişafinı sağlamada en müessir rol oynayan mühim vasıtalarından biri olarak değerlendirilir. Toplumsal duyarlılıkların oluşmasında da önemli işleve sahip olmaktadır.1 Tanzimat'tan az önce ülkemizde devlet eliyle ilk gazetenin kurulmasından sonra,2 gelişmeye başlayan matbuatın, fikir hayatımıza önemli katkılar sunduğu vakidir. Hususiyetle Osmanl1-Türk Batılılaşması ekseninde, Batı fikirleri ile birlikte, siyasî bilgi ve havadislerin halka ulaşmasında mühim rol icra etmiştir.3 Matbuat, bu yönüyle önemli olmakla birlikte, ülkenin birliği ve beraberliği, millî ve manevî değerlere sahip olma ve geliştirme bakımından da önemi haizdir. Bu bağlamda matbuat, büyük bir zaferle çıktığımız Türk Kurtuluş Savaşı'ndan sonra, Türk Milleti'nin bilinçlenmesinde, birlik ve beraberliğin tesisinde, büyük bir görev üstlenmiştir. Türk insanı cephede silahıyla düşmana galip gelirken, muharrirlerimiz de gazete sütunlarından Türk Milleti'nin bu yüce gayesini dimdik ayakta tutmaya sa'y ve gayret etmişlerdir. Milli Mücadele yıllarında matbuat zorluklarla karşılaşmış, ancak söz konusu vatan mücadelesi olunca, bütün olumsuz şartlara rağmen yayın hayatını devam ettirmeye çaba göstermiştir.4 Zaferden sonra, ülkenin yeniden tensik ve ihyası ile inşasında matbuata çok iş düşmüştür.

Mustafa Kemal, Milli Mücadele Dönemi’nde millî bir basın oluşmasına önem vermiş, desteklemiş̧ir. Zira M. Kemal, Milli Mücadele ruhunun oluşması ve gelişmesi için basına önemli vazife düştüğünün farkında ve bilincindeydi. Bu bağlamda, millî hak ve hukukun korunmasına, ayrıca Türk Milleti'nin haklarının ve amaçlarının ancak millî nitelikleri haiz matbuatla ortaya konabileceğine inanmıştır.5

1919-1922 tarihleri arasında yayın yapmaya çalışan 141 süreli yayın Milli Mücadele'nin önemli mihenk taşları arasında yer almıştır. Özellikle taşra basınına bu minvalde önemli görevler düşmüştür. Milli Mücadele yıllarında ve sonrasında taşranın Milli Mücadele yanlısı matbuatı hem millî hislere tercüman olmada, hem de millî birlik ve beraberliğin tesisinde üstün katkı sağlamıştır.

1 Servet Tiken, "Cenevre'de Bir Jön Türk Mizah Gazetesi: Tokmak”, A. Ü. Türkiyat Araştırmaları Enstitüsü Dergisi [TAED] 54, (Erzurum 2015): 404.

2 Orhan Koloğlu, Osmanlı Basınının Doğuşu ve Blak Bey Ailesi, (İstanbul: Müteferrika Yayınları, 1998): 70; Ünsal Çı̆̆, “19. Yüzyılda Osmanlı’da Gazetecilik Hareketleri: Takvim-i Vekayi’den Vilayet ve Özel Girişim Gazetelerine", Türkiye'de Yerel Basın, Editör: Suat Gezgin, (İstanbul: İstanbul Üniversitesi İletişim Fakültesi Yayınları, 2007): 43.

3 Belkıs Ulusoy Nalcığlu, Osmanlı'da Muhalif Basının Doğuşu, (İstanbul: Yeditepe, 2013): 49.

4 Zekai Güner, "Millî Mücadele'de Türk Kamuoyunu Oluşturan Basın”, Erdem, 11, no. 31, (1998): 97-98.

5 Yücel Özkaya, "Milli Mücadele Başlangıcında Basın ve Mustafa Kemal Paşa’nın Basınla İlişkileri”, Atatürk Araştırma Merkezi Dergisi 1, no. 3, (1985): 871, 882-883. 
Bu bağlamda, Millî Mücadele yıllarında ve sonrasında "millî" adıyla kurulan gazetelerin millî davamızda yer aldıkları görülmektedir. "Satvet-i Milliye (Elazı̆g)", "Amal-i Milliye (Maraş)", "Milli Mefkure (Adana)", "Milli Ordu (Ankara)", "Muvaffakiyyet-i Milliye (Ordu)", "İrade-i Milliye (Sivas), "Gaye-i Milliye (Sivas)", "Mücahede-i Milliye (Sivas)", "Milli Gaye (Bolu)" isimleriyle yayın yapan gazeteler6, Milli Mücadele’nin taşrada gözü kulağı olmuşlardır.

Bu çalışmada, Bolu Vilayeti'nde Bolu Sultanisi öğretmenlerince çıkartılan Milli Gaye gazetesinin yayın politikası, amacı ile yayınlarıyla yerelde millî birliğin tesisinde oynadığı rol ele alınmıştır. Yakın tarihimizde millî niteliği haiz yayın politikası takip eden gazetenin yerelde, millî mefkûrenin yerleşmesi ve idealize edilmesi ile Türkiye Cumhuriyeti'nin kuruluş felsefesinin anlatılması ve anlaşılmasında oynadığı rol değerlendirildiğinde; yerel basına dair yapılan bu çalışmanın, önemi ortaya çıkmaktadır.

\section{A- Milli Mücadele ve Sonrasında Milli Birlik ve Beraberliğin Tesisinde Gazetelerin Rolü}

Osmanlı Devleti'nde matbuatın vetiresi Lale Devri'ne tekabül eder. Lale Devri'nin önemli bir yenileşme atılımı olan Avrupa başkentlerine geçici elçiler gönderilmesinin kabul edilmesiyle, 1727 tarihinde 28 Mehmet Çelebi Paris'e elçi olarak gönderilmiş, bu arada beraberinde oğlu Sait Efendi'yi de götürmüştür. Sait Efendi'nin Macar asıllı İbrahim Müteferrika7 ile beraber, Lale Devri'nin en önemli teknik ianesi olan matbaanın Osmanlı ülkesine getirilmesi, önemli bir gelişme olmuştur. Darü't-Tıba'atü'l-Amire adiyla kurulan söz konusu matbaa, dönemin 'en büyük ve en tesirli” yeniliği sayılmıştır.8

II. Mahmut Dönemi’ne kadar matbaada tedrici olarak basım faaliyetleri sürdürülmüştür. $\mathrm{Bu}$ arada Sultan, Batı dünyasında haber almada önemli bir işleve sahip olan matbuatın, Osmanlı Devleti'nde neşet etmesine öncülük etmiştir. İstanbul Fransız büyükelçiliğince 1795'te Bulletin des Nouvelles, 1796' da Gazette Française de Constantinop ve İzmir'de bir süredir yayın yapan Alexandre Blackque tarafindan Le Spectateur (Mart 1821) ve Le Courier de Smyrne isimli Fransız gazeteleri ile yine Misır Vilayeti'nde çıkan Takvim-i Vekayi'den9 haberdar olunması ve bu gazetelerin öneminin anlaşılması, bir gazete kurulmasını zorunlu kılmıştır. Bu öncüller, Osmanlı Devleti'nde devlet eliyle Takvim-i Vekayi adıyla bir gazete yayınlanmasını intaç kılmıştır.10 Bu gazeteden sonra, yarı resmi hüviyette William Churchill'in 1864 tarihinde ölümüne kadar yayın yapacak olan Ceride-i Havadis ve ilk özel gazete olan Tercüman-1 Ahval ile Tasvir-i Efkar basın

6 Nazım H. Polat, “Türkiye'de Yerel Basının Gelişimine Kısa Bir Bakış”, TÜBAR, XII, (Güz 2002): 7-25; Özkaya, "Milli Mücadele Başlangıcında Basın...", 876.

7 İbrahim Müteferrika hakkında bilgi için bkz. Mustafa Asım Yediyıldız, “İbrahim Müteferrika”, Vakıflar Dergisi, 22 (1991): 441-447.

8 Şerif Korkmaz, "İbrahim Müteferrika ve İlk Türk Matbaası”, Dini Araştırmalar, cilt 2, no. 5, (Eylül Aralık 1999): 285; Osman Ersoy, Türkiye’ye Matbaanın Girmesi ve İlk Basılan Eserler, (Ankara: $\underline{\text { A.Ü. }}$ DTCF Kütüphanecilik Enstitüsü, 1959): 35.

9 Aydeniz, "Yerel Gazetecilik", 10-11.

10 Nesimi Yazıc1, Takvim-i Vekayi: Belgeler, (Ankara: Gazi Üniversitesi Yayınları, 1983): 20; Orhan Koloğlu, Takvim-i Vekayi: Türk Basınında 150. Yll: 1831-1981, (Ankara: Ankara Basım Sanayi, 1982): 41; Orhan Koloğlu, İlk gazete, İlk Polemik: Vekayi-i Mısriye'nin Öyküsü ve Takvimi Vekayi ile Tartışmasl, (Ankara: Çağdaş Gazeteciler Derneği, 1989): 43; Orhan Koloğlu, "Osmanlı Basını, İçeriği ve Rejimi”, Tanzimat'tan Cumhuriyet'e Türkiye Ansiklopedisi, hazırlayan Murat Belge-Fahri Aral, cilt I, (İstanbul: İletişim Yayınları, 1985): 69-70. 
hayatının gelişiminde öncü rol oynamışlardır.11

"Tanzimat hareketlerinin su-i generis-i olan vilayet matbaaları"12nın kurulmaya başlaması, yerel matbuatın ortaya çıkmasına vesile olmuştur. 1864 tarihinde Tuna Vilayeti ile başlayan ve daha sonra birçok vilayette teşekkül eden vilayet matbaalarının kurulması ile yayın hayatına kazandırılan yerel gazeteler, taşra insanının malumat sahibi olmasında mühim rol oynamıştır. Aslında Osmanlı'da yerel basınla ilgili ilk gelişme Beyrut Vilayeti'nde karşımıza çıkmaktadır. Fuat Paşa'nın baş gösteren karışıklık üzerine görevlendirildiği Beyrut'ta Hadika al-Ahbar adıyla yerel bir gazetenin kurulmasına öncülük etmiştir. Bu gazeteden sonra Tuna Vilayet gazetesi yerel gazeteciliğin gelişiminde mühim bir mevkie sahip olmuştur. Bunu sırasıyla 1865 'te Suriye, 1866'da Trablusgarp, 1867'de Gadir el Firat, Lübnan, Envar-1 Şarkiye ve Girit gazeteleri takip etmiştir. Bu ilk yerel gazetelerden sonra 28 taşra gazetesi yayın hayatına başlamış, bu sayı 1908'de 36'ya ulaşmıştır.13 Yerel gazeteciliğin Anadolu'da ilk örneği Erzurum'da çıkan Envar-1 Şarkiye (1866)'dir.14 Bu gazetenin basıldığ vilayet matbaası, birçok vilayete örneklik teşkil etmiştir. Sayıları 30'u bulan söz konusu matbaalarda 42 vilayet gazetesi çıkarılmıştır.15 20. Yüzyılın başında bugünkü Türkiye sınırları içinde 145 matbaa faaliyet göstermekteydi. "Vilayet matbaa ve gazeteleri, taşrada birer kültür adacıkları oluştur"muşlardır. Giderek yaygınlaşan bu kurumlar, Osmanlı taşrasında küçümsenmeyecek tesirler meydana getirmişlerdir.16

Vilayet gazeteleri taşranın sesi kulağı olmuş, Anadolu insanının belleğinde yeni imaja sahip olmuştur. Özellikle Milli Mücadele ve sonrasında yerel basın, 4. kuvvetin çok daha ötesinde bir etki meydana getirerek, birlik ve beraberliğin tesisinde görev alarak, vatanî bir görev üstlenerek, Türk Milleti'nin ve vatanının kurtuluşunun tesisinin baş aktörlerinden olmuştur. Millî Mücadele'nin teşkilatlanmasında mühim bir görev üstlenmiş olan matbuat; kamuoyu oluşturmada, birlik ve beraberliğin tesisinde, 17 toplumun "tenvir ve terbiye"sine 18 çalışmıştır. Hususiyetle; ahlakî, siyasî, millî ve tarihî değerleri içselleştiren ve onu öncelleyen bir yayın politikası takip eden, ayrışma yerine bütünleştirici ve birleştirici bir felsefi anlayışa sahip olan millî niteliği haiz matbuat, Türk Milleti'nin hem Millî Mücadele sırasında hem de Türkiye Cumhuriyeti'nin kuruluş ve gelişimi sırasında sergilediği kararlı duruşla; bütüncül, siyasal ve toplumsal fikir ve bilincin gelişmesine zemin hazırlamıştır.19

Milli Mücadele yanlısı Anadolu ve İstanbul matbuatı halka doğru bilginin verilmesini sağlamıştır. Bu minvalde yayın yapan İstanbul matbuatı, işgal güçlerinin baskısıyla İstanbul

11 Hıfzı Topuz, 100 Soruda Türk Basın Tarihi, (İstanbul: Gerçek Yayınevi, 1973): 9-10; M. Nuri İnuğur, Basin ve Yayın Tarihi, (İstanbul: Der Yayınları, 1993): 190.

12 Uygur Kocabaşoğlu, “Tuna Vilayet Gazetesi”, OTAM (Ankara Üniversitesi Osmanlı Tarihi Araștırma ve Uygulama Merkezi Dergisi), no. 2, (1991): 141.

13 Olcay Uçak-Abdi Erkal, "Osmanlı'dan Günümüze Türkiye'de Yerel Basının Gelişim Süreci”, Selçuk İletişim, 2019, 12 (1): 94; Orhan Koloğlu, Osmanlı'dan Günümüze Türkiye’de Basın, (İstanbul: İletişim Yayınlar1, 1994): 20.

14 Cavit Orhan Tütengil, "Olaylar ve Görüşler”, Cumhuriyet, (11.7.1971): 2.

15 Polat, "Yerel Basının Gelişimi”, s. 9.

16 Kocabaşoğlu, "Tuna Vilayeti Gazetesi”, 143.

17 Fahri Kılıç, “Millî Mücadele Döneminde Türkoğlu Gazetesi”, Yakın Dönem Türkiye Araştırmaları, 36, (2019): 50.

18 Kocabaşoğlu, “Tuna Vilayet Gazetesi”, 141.

19 Uçak - Erkal, "Yerel Basının Gelişim Süreci”, 97. 
Hükümeti'nce baskıya ve sansüre tabi tutulmuştur. Milli Mücadele'nin yılmaz savunucusu olan Anadolu'nun millî basını, oldukça zor şartlara rağmen, millî direnişte önemli hizmetlerde bulunmuştur. Millî duyguları şahlandıracak yayınlara yer veren millî matbuat, Millî Mücadele’nin zafere ulaşmasında mihenk taşlardan biri olmuştur.20 Zira Anadolu matbuatı Millî Mücadele'nin en büyük yardımcısı hüviyetine sahipti. Anadolu matbuatının hem işgal altında olmayan bölgelerde olması hem de İstanbul Hükümeti'nin baskısından uzak oluşu dikkati müciptir. Millî Mücadele'nin başarıya ulaşmasında oynadığı rolü, Büyük Millet Meclisi’nin kurulmasında21 ve sonrasında da göstermiştir.

Kurtuluş Savaşı Dönemi şartlarında Türk Milleti'nin Millî Mücadele hareketinden haberdar edilmesinde ve gelişmeler hususunda bilgilendirilmesinde basın önemli bir güç olmuş ve toplumu etkilemiştir. Kamuoyunun Millî Mücadele’ye katılmaya ve desteklemeye teşvik edilmesi basın aracılığıyla gerçekleştirilmiştir. Millî ve manevî olgular, vatanın kurtuluşu ve selametine dair yazılar basın vasıtasıyla duyurularak, halk birlik ve beraberliğe sevk edilmiştir. Dolayısıyla Millî Mücadele Basını22, millî karakteri haiz tarihine, değerlerine bağlı bir basındır. Özellikle siyasal ve toplumsal belirsizlik ortamında Türk Milleti'ni Millî Mücadele etrafında toplamada ve bu amaca destek verilmesini sağlamada Milli Mücadele yansılı basına ihtiyaç vardı. Bu bağlamda M. Kemal "millı̂” ismiyle İrade-i Milliye ve Hakimiyet-i Milliye adıyla gazetelerin kurulmasını sağlayarak, Millî Mücadele'de kamuoyu oluşturulmasını sağlamıştır.23

M. Kemal, Millî Mücadele'nin örgütlü karaktere kavuşturulmasında basının itici güç olduğunu bildiğinden dolayı Millî Mücadele'nin her safhasında basını önemli bir güç olarak görmüştür. Zira bu dönemde hem İstanbul'da hem de Anadolu'da Millî Mücadele karşıtı bir basın vardı.24 Bu basının tüm zararlı yayınlarını etkisiz bırakmak için Millî Mücadele’yi destekleyen basının güçlendirilmesi ve sayısının çoğaltılması elzemdi.25

Milli Mücadele'nin zaferle neticelenmesinden sonra Türkiye Cumhuriyeti'nin kuruluşu, gelişimi ve inşasında matbuat önemli görevler üstlenmiş, özellikle yerel basın bu bağlamda oldukça dikkate değer çaba sarf etmiştir. Türkiye Cumhuriyeti'nin siyasal kurumlarıyla şekillenmesinin sağlanmasında ve kurumların tanıtılmasında basına önemli görev düşmüştür. Özellikle sosyal, kültürel ve iktisadî açıdan olduğu kadar; modern toplum örgütlenmesinde yadsınamayacak işlere imza atmıştır. Bunun yanı sıra cumhuriyetin öngördüğü yeni toplumsal yapının şifrelerinin neşet etmesinde de yerel basına önemli görevler düşmüştür. Ayrıca yeni "siyasal yapı ve toplumsal örgütlenmenin" 26 anlaşılması, yerelde kabul görmesi, bu bağlamda anlamlı gözükmektedir. Türkiye Cumhuriyeti'nin siyasal meşruiyet alanının sağlanmasında yerel basın öne çıkmaktadır. M. Kemal, hem Millî Mücadele sürecinde hem de Türkiye Cumhuriyeti’nin kuruluş ve gelişim

20 K1lıç, "Millî Mücadele Döneminde Türkoğlu Gazetesi”, 51-52.

21 Güner, "Millî Mücadele'de Türk Kamuoyunu Oluşturan Basın”, 97.

22 Ulusoy, "Milli Mücadele, Propaganda, Atatürk ve Basın", 56.

23 Uğur Gündüz, “Kurtuluş Savaşı’nda Yerel Basının Rolü”, Türkiye’de Yerel Basın, Editör Suat Sezgin, (İstanbul: İstanbul Üniversitesi İletişim Fakültesi Yayınları): 91.

24 Hülya Baykal, "Milli Mücadele'de Basın”, Atatürk Araştırma Merkezi Dergisi, 4, no. 11, (Mart 1988): 35.

25 Sezen Kılıç, "Cumhuriyetin İlk Yıllarındaki Gelişmeleri Basının Yorumlayışı (1923-1926)”, Atatürk Araştırma Merkezi Dergisi, 24, no. 70, (2008): 150.

26 Hediyetullah Aydeniz, "Tarihsel ve Literal Açıdan Yerel Gazetecilik”, Türkiye'de Yerel Basın, Editör Suat Sezgin, (İstanbul: İstanbul Üniversitesi İletişim Fakültesi Yayınları): 3-4. 
sürecinde basının önemli bir güç olduğunu ve her iki mücadeleye de dinamizm kazandırdığının bilincinde ve farkında olmuştur.27 Bu noktada basının dördüncü güç olarak görülmesi hiç de şaşırtıcı karşılanmamalıdır. Yerel basın toplumun bilgilendirilmesinin yanı sıra yerelde "toplumun yeni düzeni anlama ve buna uyumunu sağlamada"28 Mustafa Kemal, basının önemli bir vasıta olduğunu her düzlemde göstermiştir. Millî Mücadele yıllarında "basını bir silah olarak kullanmayı tercih etmesi" 29 bunun delilidir.

Millî Mücadele sırasında vatanın kurtuluşu için mücadele veren millî basın, daha ziyade dışa dönük yayın politikasını, Millî Mücadele'nin başarıya ulaşmasından sonra içe dönük yayın politikasına dönüştürür. Ankara' daki siyasal gelişmeler özellikle Meclis ile ilgili haber ve yorumlara ağırlık verilir. Hakimiyet-i Milliye ve Yeni Gün gibi millî nitelikteki gazeteler Ankara Hükümeti yanlısı yayınlarıyla öne çıkar. Bu gazetelerin destekleri siyasal meşruiyet açısından oldukça önemli ve dikkat çekicidir. Aynı zamanda İstanbul'da Akşam ve İleri gazetelerinin de Ankara'yı destekleyen yayın politikası takip etmesi bu bağlamda anlamlıdır. Ankara Hükümeti'nin icraatları doğrultusunda fikir ortaya koyan basın, hükümetin önemli itici gücü olmuştur.30 Bu destek özellikle cumhuriyetin ilanında daha da önemli hale gelmiştir. Yenigün gazetesinde Feridun Fikri Bey'in "Hakimiyet-i Halkiyye" adıyla kaleme aldığı yazısında gazetenin açıkça cumhuriyeti desteklediğini ortaya koyduğu görülmektedir.31 Ayrıca Millî Mücadele'nin sözcüsü olan Hakimiyet-i Milliye, Millî Hakimiyetin savunucusu olmuş, cumhuriyetin değerleriyle barışık bir yayın politikası takip etmiştir. M. Kemal, cumhuriyetin ilanına kamuoyunun hazırlanmasında basının oynayacağı rolün bilincindeydi. İzmit'te basın toplantısına katılan İstanbul basın mensuplarına "hükümet şeklimizin niteliğini anlatmak gereklidir." 32 derken, basının bu hususa dair kamuoyunu bilgilendirmelerinin elzem olduğuna vurgu yapmıştır.

\section{Milli Gaye Gazetesi ve Milli Birlik ve Beraberliğin Tesisinde Oynadığı Rol Yayın Politikası}

Milli Gaye Gazetesi, Milli Mücadele'nin 11 Ekim 1922 tarihinde Mudanya Mütarekesi'nin imzalanıp fiili savaşın bitiminden 20 gün sonra, yayın hayatına başlamıştır. Milli değerlere sahip ilkeli bir yayın takip eden gazete, 1 Kanunuevvel 1338 (1 Aralık 1922) tarihi ile 1 Nisan 1339 (1 Nisan 1923) tarihleri arasında 9 sayı çıkmıştır. Üçbuçuk ay yayımlanabilmiştir. Bolu Vilayet Matbaasında basılan gazetenin sahibi, imtiyaz ve mesul müdürü Sultanî müdürü Süleyman Avni Bey'dir.33 Gazetedeki yazıları S. A. imzasıyla yayınlanır. "İçtimâ̂, edebî, fennî, tarihî mecmuadır"

27 Özkaya, "Milli Mücadele Başlangıcında Basın”, 871, 882-883.

28 Aydeniz, "Tarihsel ve Literal Açıdan Yerel Gazetecilik", 5.

29 Belkıs Ulusoy, "Milli Mücadele, Propaganda, Atatürk ve Basın”, İstanbul Üniversitesi İletişim Fakültesi Dergisi, no. 20, (2004): 56.

30 Nurettin Güz, “Cumhuriyetin İlanına Basının Bakışı”, Selçuk İletişim, 1, no. 1, (1999): 4-6.

31 Ramazan Tosun, "Cumhuriyetin İlanında Kamuoyu”, Selçuk Üniversitesi Türkiyat Araştırmaları Dergisi, no. 12, (2002): 102.

32 Hatice Akman - Samed Kurban, "Osmanlı'da Basın Hareketlerini Yeniden Düşünmek: Meşrutiyet ve Cumhuriyet Dönemlerine Bakış”, 4. Uluslararası Kültür Ve Medeniyet Kongresi, https://www. europenjournal.com/ Kongre Tam Metin Kitab1, (Mardin, 2018): 426, 434-435.

33 Süleyman Avni Bey, Bolu Vilayet Salnamesinde Bolu Erkek Orta Mektebi müdürü olarak geçmektedir. Bkz. Bolu Livası Salnamesi, 1921-1922, (Bolu: Bolu Hükümet Matbaası, 1922): 187. 
klişesiyle yayın hayatına başlayan gazete, Sultanî34 heyeti talimiyesi tarafından 15 günde bir neşir olunmuştur. Her sayı 6 sayfadan oluşmaktadır. Gazete aboneliği için imtiyaz sahibine müracaat edilmesi gerektiğinden bahsedilmektedir. Gazetenin Mütekait Binbaşı Tahsin Bey’in yazıhanesi, çarşı içinde Attarlar civarında Erzincanlızade Tevfik Efendi (Zafer-i Milli) kitaphanesinden temin edilebileceği belirtilmektedir. Nüshası 10 kuruştur.35 Vilayet matbaasında basımı yapılan gazetede, sade ve anlaşılır bir yazı dili kullanılmıştır.

Gazetenin ele aldığı konular çerçevesinde Türk millî kimliğinin inşasına çalışan Türkçü bir yayın organı olduğu söylenebilir. Okurlarında Türklük bilincinin gelişimine kısa süreli yayın hayatında önemli katkılar sunduğu anlaşılmaktadır. Yazar kadrosunun Sultanî Mektebi öğretmenlerinden müteşekkil olmasından dolayı gazetede eğitime, bilime ve terakkiye dair konular daha ön planda tutulmaktadır. Gazete ileride ilan edilecek cumhuriyetin temel ilkelerini ele alarak, bu ilkeleri halka anlatmaktadır. Bununla halk cumhuriyete 1sındırılmakla beraber, cumhuriyet ve ona dair kavram ve felsefenin daha iyi anlaşılmasına hizmet sunduğu söylenebilir. Yeniliklere olan gereksinimlerin zarureti okurlarına izah edilerek, cumhuriyet inkılaplarının benimsenmesini sağlamada taşrada önemli bir vazife ifa ettiği belirtilebilir.36

Gazete yayın ilkelerini "Maksad ve Meslek" başlıklı yazısında ortaya koymaktadır. Her ne kadar yerel bir gazete gibi gözükse de yazar kadrosunun eğitimci olmasından olsa gerek, ele aldığı konular, vatanın ihyasının temin ve tesisi üzerinedir. Toplumsal meseleler gazetenin öncelikleri arasındadır. Toplumu bilgilendirmek, özellikle eğitim ve öğretime katkı sağlamak önem verdiği hususlardır. Memleketin 14 seneden beri geçirdiği maddî ve manevî buhran sebebiyle Türk Milleti'nin ve vatanının pek çok gaile ile karşı karşıya kaldığını, özellikle içtimaî hayatımızın fikrî gıdasızlık neticesi, yüksek bir "faaliyet-i ilmiye" gösteremediğini belirtmektedir. "Harb ve cidal" senelerinin tesiriyle eğitim ve kültür hayatımızda ciddi sıkıntılarla karşı karşıya kalındığını, söz konusu sıkıntıların giderilmesi için Milli Mücadele'de düşmana karşı büyük bir zafer kazanan bütün efrad-1 milletin bu sahada da mücadele etmesinin mecburi olduğunun altını çizmektedir. Herkesin milletine ve vatanına hizmeti; ahlakî, millî, hissî ve siyasî bir borç olarak görmektedir. Gazetenin yazı heyeti, bu bağlamda gayesini şu şekilde izah etmektedir: "İște, bu günün her münevveri gibi biz de Sultani Heyet-i Talimiyesi memleketin bu ilmi ihtiyacını bir zerre olsun tatmin etmek maksadıyla Milli Gaye Mecmuasını mevki-i intişara vaz' ediyoruz. Gayenin mevzu-1 Türk Milleti'nin kendi ruhi gayesidir. Kendi gayesidir. Binaenaleyh gayemizin mevzuu ve gaye ittihaz ettiği Türk halkından teveccüh ve iltifat göreceğine kaniyiz.’37

Gazete birlik ve beraberliğin tesisinin önemine değinerek, bir toplumun aynı duygular etrafında toplanmasının elzem olduğunu ifade etmektedir. Millî gayenin bütün Türk ilinin faydasına ve hayrına çalıştığı gibi Bolu muhitinin sorunlarını, ihtiyaçlarını gazete sütunlarına taşıyarak, Bolu idaresinin dikkatini çekmeye çalışmaktadır.38 Millî hisleri ve duyguları önceleyen gazetede

34 İdadiler, 1910 tarihinde Sultaniye dönüştürülmesinden sonra, 1914 tarihinde Bolu İdadisi, Bolu Sultanisi adını almış, daha sonra da Bolu Erkek Orta Mektebi adını almıştır. Bkz. Fahri Kılıç-Murat Tarhan, “Tanzimat’tan Cumhuriyet’e Bolu'da Eğitim Uygulamaları”, AiBB̈̈ Sosyal Bilimler Enstitüsü Dergisi, 14/14, no. 3, (2014): 173.

35 Milli Gaye, no. 2, (15 Kanun-1 Evvel 1338): 1.

36 M. Besim, "Halkçılık", Milli Gaye, no. 6, (5 Şubat 1339): 2, 3.

37 "Maksad ve Meslek", Milli Gaye, 1, no. 1, (1 Kanunuevvel 1338): 1.

38 "Nelere İhtiyaçlarımız Var", Milli Gaye, 1, no. 6, (5 Şubat 1339): 3. 
"İzcilik" başlığı ile yayınlanan yazıda "Vatan yavrularına verilecek millî, fikrî ve ahlakî terbiye, bedenî terbiye ile beraber verilmedikçe vücuda muvazenet tesis edemeyeceğinden, hiçbir faide hasıl olmayacağı" belirtilerek izciliğin bu kapsamda önemine vurgu yapılmaktadır.39

Gazetede, millî birlik ve beraberliğin tesisi istikametinde yayın politikası takip ettiğinden, toplumu bilgilendirme ve bilinçlendirme ön plandadır. Karmaşı siyasal konular ve tartı̧malardan okuyucularını uzak tutarak, tefrikaya yol açacak bahisler ve yorumlardan kaçınmıştır. Daha ziyade Türkiye'nin temel prensiplerinin anlaşılmasına dair yazılara yer vererek, birlik ve beraberliği temele alan yayın politikası izlemeyi gaye edinmiştir. Toplumdaki hastalıkları, sıkıntıları ele alarak, sorunların izalesi bağlamında yazılar kaleme alarak, halkın bilinçlenmesine çalışmıştır. İsmiyle müsemma olan Milli Gaye gazetesine genel olarak bakıldığında, yayın politikasıyla hedefine ulaştığı anlaşı1ır. Politik konular ve yorumlar millî birliği tesis edecek niteliklere sahiptir. Kuruluş Savaşı'nda olduğu gibi, zafer sonrasında da millî birliğe şiddetle ihtiyaç duyulduğundan, özellikle Türkiye'nin politikalarını, hedeflerini yerelde halka anlatması, gazeteyi önemli ve anlamlı kılmaktadır.

\section{Tarih Şuur ve Bilincinin Kazandırılması}

Gazete millî duyguları ön planda tutan milliyetçi bir yayın politikası takip etmektedir. "Hür ve müstakil yaşamak Türkün asli bir seciyesi" diyen gazetede, Türklük şuur ve karakteri ön plana çıkmaktadır. Bu şuur, Milli Mücadele'nin başarıya ulaşmasındaki en büyük amil olmuştur. Burada millî birlik ve beraberliği üst düzeyde tutmanın millet ve memleketin bekası ve istiklali için önemi haiz olduğunun altı çizilmektedir. Türkün istek, temenni ve beklentisini ise şu şekilde ele almaktadır: "Her zaman hakkın müdâfii olmak tarihi bir vazifesi, her yerde hürriyeti görmek de samimi bir arzusudur." Türk'e bu ulvî seciyeyi, mukaddes vazifeyi veren ise "ahlakı, vicdanı, içtima1 teşkili, tabiat kadar derin ve geniş imanı, ezeliyet ve ebediyet kadar büyük tarihidir.” Türk Milleti'nin tarih şuur ve bilinci, derin imanı ile Türk vatanının kurtuluşunu gerçekleştirdiğine yürekten inanmaktadır. Aynı zamanda "Yüksek seciyesini hiç değiştirmediğine insaniyetin tarihi hakikatin vicdanı şahiddir. Daima bu mübarek yolda gideceğine ve daima muzaffer olacağına ebedi imanı kamildir." diyerek tarih boyunca Türk Milleti’nin karakterinin değişmediğini ve bu yolda ilerlediğinde her daim muzaffer olacağını belirtmektedir. "Maziye dair tarihî vesaikin şehadeti ve bu güne aid hadisat, Türkün tabiat ve ahlakı üzerinde yapılan ictimaî ve ruhî tedkikat bize isbat ediyor ki Türk hiçbir zaman harici tahakkümün azab ve ızdırabını çekmemişdir, çekmez. Hiçbir yerde tahakkümün vücudunu göremez. Adeta hürriyetin samimi bir sevdalısıdır."40

Gazete, Türkün vatan aşkının ve sevdasının uğrunda maddî ve manevî kuvvetini sarf etmeği bir vazife, icabında ölmeği de bir şeref bildiğini, Türk Milleti'nin vatanının beka ve istiklal sorunu yaşadığında canını feda etmekte hiç tereddüt göstermediğini, göstermeyeceğinin altını çizmektedir. Şöyle devam etmektedir: "Bu vazife ve istiklal hissinin bu kadar derin ve geniş bir surette tecelli ve inkişafı bize Türkün mutlaka serbest yaşamak serbest yaşanmak ihtiyaç-1 ruhiyesinde olduğunu izah ediyor." Gazete, Türkün maziden getirdiği engin seciyesi ile hür ve müstakil yaşamayı şiar edinmesiyle zafere ulaştığını söylemektedir. Türkün bu seciyesinin yanında geçmişte bilim, sanat ve teknikte üstün olduğunu, bundan böyle söz konusu sahada da başarılı olacağına inandığını,

39 Sultanî Terbiye-i Bedeniye Muallimi Eşref Tufan, "İzcilik”, Milli Gaye, 1, no.6, (5 Şubat 1339): 5.

40 M. Besim, "İçtimar Hayatımıza Umumi Bir Nazar", Milli Gaye, 1, no. 1. (1 Kanunuevvel 1338): 1. 
ancak bunun ciddi bir çalışmayla, fedakârlıkla, azimle gerçekleşeceğini savunmaktadır.41

Gazete, Lozan Konferansı görüşmeleri ve Türkiye'nin millî davasından bahsederken bu bağlamda 5. Nüshasında "Milli Gayemiz Nedir?" diye soruyor.42 "Hiçbir milletin hukukuna tecavüz etmemek şartıyla biz de diğer milletler gibi hudud-1 milliyemiz dahilinde kânûn-1 medeniyetin ahkâmı dairesinde istiklâli tamm ile yaşamakdan başka bir şey olmadığını her vasıta ile cihana ilan etmektir" devletin beka ve istiklalinin temininin önemine vurgu yapan gazete, düşmanların "istilakar makasıdına karşı mülkümüzün muhafazasını ve vesait-i müdafaadan mahrum bırakılmamasını" istemektedir. Bundan daha haklı daha meşru bir arzu olamaz diye de devam ettirmektedir.

Gazetenin ikinci nüshasında H.T. isimli yazarın "Hitabe"43 adıyla "Büyük Mustafa Kemal Paşa Hazretlerine" ithaf ettiği şiirinde geçen şu ifadeler, Türk Milleti'nin hislerine tercüman olmaktadır. "Irk-1 necibi kurtarmak için, azimle dünyaya meydan okudum. Tarih tekerrürdür dedim silkindim, eski zaferlerden destan okudum. Tekbirimi duydu gökte melekler, icabet eyledi Allah u Ekber."

Osmanlı Devleti'nin Mondros Ateşkes Antlaşması'nı imzalamasından sonra ülkemizin dört bir yanı İtilaf Devletlerince işgale uğramıştır. Bunun yanı sıra Yunanistan'da sözde Megali İdea çerçevesinde ülkemizde Bizans'ı yeniden canlandırma hülyası ile işgalde yerini almıştır. Ülkemizde Türkün adaletli ve müsavi idaresi ile yüzyıllarca rahat bir hayat yaşama imkânına sahip olmuş olan yerli gayrimüslimler, işgale sevinmişler ve desteklemişlerdir.44 Milli Gaye gazetesinde S. A. kısaltmasıyla "Gayr-1 İhtiyarı Bir İtiraf" 45 başlıklı yazıda bununla ilgili yaşanmış bir anıya yer verilir. Bakkal Yapasoğlu Galinos isimli Rum'un Yunan harekâtı başladığında, Ödemiş’in Yunan işgaline uğramasından sonra diğer gayrimüslimler gibi sevindiğinden bahseder.

\section{İktisadî Gelişmeye Dair Görüşler}

Devletin ve milletin refahının ve saadetinin temininin millî iktisattan geçtiğinin altını çizmektedir. Bir milletin ruhunun diş ticaretteki rolü olduğunu belirten gazeteye göre, iktisadî hayat için en önde gelen düsturun itimat olduğunu savunmaktadır.46 Bu ilkenin toplum arasında karşılıklı güven duygusu ile toplumsal dayanışmanın sağlıklı bir biçimde gelişmesini sağlayacağ kanaatindedir.47

Gazete, Türkiye'nin maddi gelişmesinin önemine vurgu yaparak, iktisadî hayatın canlanması, ülkenin imarının el birliğiyle yapılması gerektiğini, bunun ise bir dayanışma ruhunun vücuda getirilmesiyle mümkün olabileceğini belirtmektedir. Bu dayanışmacılık Ziya Gökalp'in savunduğu Solidarizm adı verilen dayanışmacılık temelli bir yaklaşım olduğu düşüncesini uyandırmaktadır.48 Türkiye'nin gelişmesinin sadece manevî cephe ile değil maddî cepheden de gelişimini sağlamanın

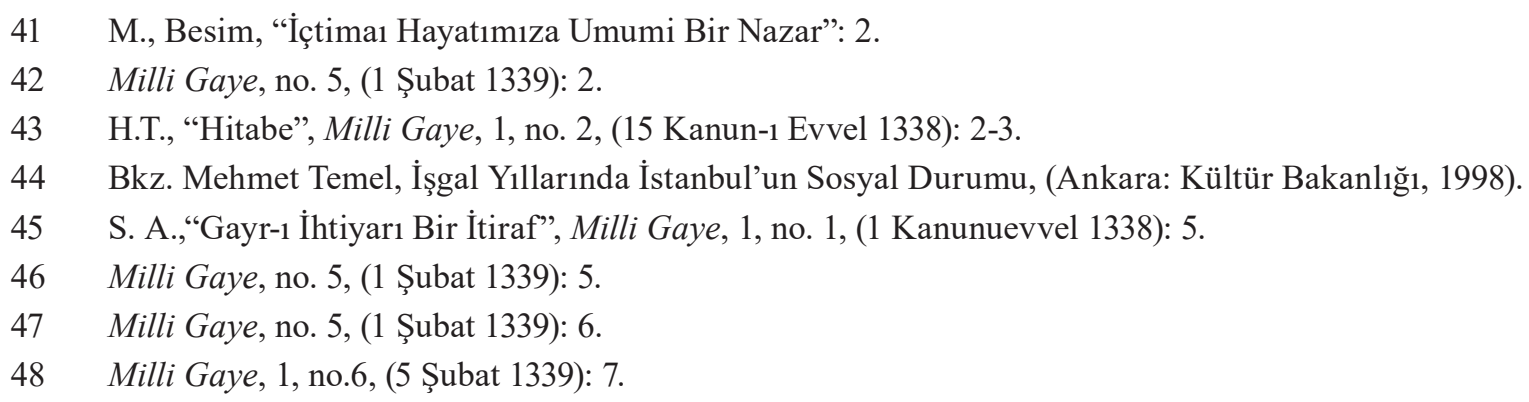


önemine değinmektedir.

Gazetenin, Mustafa Kemal'in “Arkadaşlar, bundan sonra mühim zaferlere kavuşacağız. Bu zaferler, süngü ile değil, iktisat ve ilim zaferleri olacaktır" sözünden etkilendiği açıktır. Çok zeki olan Türk Milleti'nin içinde bulunduğu maddî sıkıntıları bertaraf etmenin yolu çok çalışmaktan geçtiğini vurgulayan gazete, okumanın ve okutmanın millî, içtimaî ve hayatî bir zaruret, ahlakî bir meziyet, insanî bir fazilet olduğunu belirtmektedir.49

\section{Millî ve Manevi Değerlere Verdiği Önem}

Gelişen ve değişen şartlara, toplumlar bunlara duyarsız kalamaz. Gazete toplum bünyesini bozmayacak ve toplumun fikrî ve ilmî açıdan ilerlemesini sağlayacak gelişmelerden faydalanılmasının zarurî bir ihtiyaç olduğunu savunmaktadır. Ancak toplumun kültürel değerlerine uygun olmayan şeylerin ise alınmamasının toplumun ve devletin devamlılığı ve korunması açısından son derece önemli olduğunun altını çizmektedir.50 İçtimaî hayatımızın seciye ve karakterimizin üstün özelliklerine yer verilerek, özellikle "asabiyet-i İslamiyet'i”" unutmamamız gerektiğini vurgulamaktadır.51 Toplumsal ve dinî meselelere dair önemli konulara yer vererek toplumun tenvir edilmesine imkan sağlamaktadır. Örneğin "nikah" meselesi ele alınarak toplumun bu hususa dair bilgi eksikliğinin giderilmesine çalışıldığı görülmektedir.

"Şüheda-yı ziyaret" başlı̆ğ ile kaleme alınan yazıda ise vatanı uğruna şehit olanlara saygı duymanın, onları ziyaret etmenin millî bir vazife olduğu belirtilerek, gençlere vatanlarını her zaman müdafaa etmelerini, her daim uyanık olmalarını ögütleyerek gençlerin vatanlarına samimi hisler beslemelerini sağlamayı amaçlamaktadır. Vatan için şehit olan şühedalara saygı gösterilmesinin vatanî, vicdanî ve dinî bir görev olduğunu vurgulamaktadır. Ayrıca vatanları için şehit olanların geride bıraktıklarına sahip çıkmanın da vatani bir yükümlülük olduğu vurgulanır, önemine değinilir. Vatanın kurtuluşu ve selameti için maddî ve manevî büyük bir mücadele örneği sergileyenlere karş1 "Allah cümlenizden razı olsun" diyerek şühedalara seslenir; "şen ve güzel köylerimizden binlerce fersah uzakta yan yana dizilen şu mübarek kabirleriniz önünde büyük huzurunuzda kemal-i hudû ile durur ve takdîs ederken size layık olmayan göz yaşlarımı döker mübarek ruhlarınıza Fatihalar yollarım"52

Gazete politik ve sosyal konuları da sütunlarına taşıyarak, toplumu bilgilendirmiştir. 5. ve 6. sayıların birinci sayfalarında Boğazlar Meselesi başlığıyla boğazlara dair tafsilatlı bilgi vererek, mezkûr meselenin taşrada anlaşılmasını sağlamıştır.53 Bazı kavramları sütunlarına taşımış, halkın daha iyi anlayabilmesine katkı sağlamaya gayret sarf etmiştir. Özellikle "halkçılık" kavramı üzerinde duran gazete söz konusu kavramın önemine vurgu yapmışıtır.

Gazete toplumun sağllk hususunda da bilinçlendirilmesinin önemine değinir. Bu sebeple toplumun beden sağlı̆̆ına da önem vermektedir. "Dişler" 54 başlıklı yazıda çocukların diş serüvenini ele alarak, anneleri, bebeklerin diş gelişimi ve sağlığına dair bilgilendirmektedir.

49 M. Besim, "İçtimaı Hayatımıza Umumi Bir Nazar", Milli Gaye, 1, no. 1, (1 Kanunuevvel 1338): 2.

50 S. Avni, "Mesahabat", Milli Gaye, no. 2, (15 Kanunuevvel 1338): 1.

51 Milli Gaye, no. 5, (1 Şubat 1339): 3.

52 Milli Gaye, no. 5, (1 Şubat 1339): 5.

53 Abdurrahman Şeref, "Boğazlar Meselesi”, Milli Gaye, 1, no. 5, (1 Şubat 1339): 1; (5 Şubat 1339): 1

54 Milli Gaye, 1, no. 1, (1 Kanunuevvel 1338): 5. 


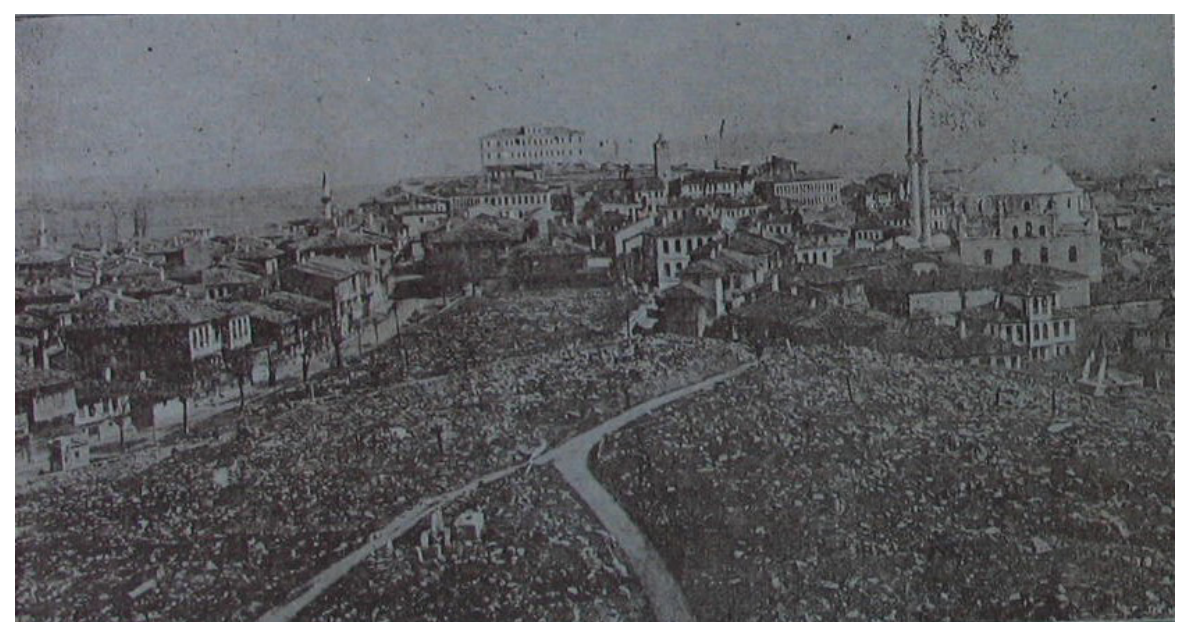

Milli Gaye, Sayı 5, sayfa1

\section{Eğitim Öğretime Dair Görüşler}

Millî hislerin güçlenmesi ve birliğimizin devamının sağlanmasında eğitimin oldukça önemli olduğunun altı çizilmektedir. Millî değerleri temele alacak bir eğitimin birlik ve beraberliğin tesisinde büyük rol oynayacağı ifade edilmektedir. Devletin ve milletin geleceğinin teminat altına alınmasında eğitime büyük ihtiyaç olduğundan, ona ehemmiyet verilmesinin gereğine işaret etmektedir. "İlk Mektepler Nasıldır, Nasıl Olmalıdır?”55 başlıklı yazıda, çocuk pedagojisine yer verilmektedir. Geleceğimizin teminatı olan çocuklarımıza okulun sevdirilmesinin önemine değinilmektedir. Bu hususta öğretmenlere çok iş düştüğünün, öğretmenlerin çocuk psikolojisinden anlamaları gerektiğinin ve onlara oryantasyon sağlayarak okulu sevdirmelerinin öneminden bahsedilmektedir. Çocukların eğitim öğretim hayatının başarılı ve verimli olabilmesinin okulun onlara sevdirilmesinden geçtiğini savunmaktadır.

Edebiyat ve şiire yer veren gazetenin özellikle millî duygulara terennüm olan şiirlere daha çok yer verdiği görülmektedir. Şiirler millî hislerin daha da güçlenmesini sağlayarak millî birlik ve beraberliğin teminine önemli katkı sağlamaktadır.56

\section{Sonuç}

Yerel basının toplumun tenvirine ve inkişafına önemli katkı sağladığının anlaşıldığı çalışma ile Milli Gaye gazetesinin özellikle Kurtuluş Savaşı ve sonrasında Türk Milleti’nin birliği ve beraberliğinin tesisine büyük önem verdiği görülmektedir. Millî ve manevî değerleri temel alan bir yayın politikası takip eden gazetenin Bolu Sultanisi öğretmenlerince çıkartılması, gazetenin eğitim başta olmak üzere, toplumun bilgilendirilmesi önceliği arasındadır.

Milli Gaye gazetesi Bolu Vilayeti'nin eğitim başta olmak üzere sosyal ve kültürel meselelerine önem vererek, halkın bilgi sahibi olmasında öncü rol oynadığı anlaşılmaktadır. Özellikle Türkiye'nin öncelik verdiği kavramlara yer vererek, bu kavramların daha iyi anlaşılmasına katkı sağladiğı görülmektedir. 


\section{Kaynaklar}

“Maksad ve Meslek”, Milli Gaye, 1, no. 1, (1 Kanunuevvel 1338)..

Akman, Hatice - Samed Kurban (2018). “Osmanlı' da Basın Hareketlerini Yeniden Düşünmek: Meşrutiyet ve Cumhuriyet Dönemlerine Bakış”, 4. Uluslararası Kültür Ve Medeniyet Kongresi, https://www.europenjournal.com/ Kongre Tam Metin Kitab1, Mardin.

Aydeniz, Hediyetullah (2018). "Tarihsel ve Literal Açıdan Yerel Gazetecilik”, Türkiye’de Yerel Basın, Editör Suat Sezgin, İstanbul: İstanbul Üniversitesi İletişim Fakültesi Yayınları.

Baykal, Hülya (1988). "Milli Mücadele'de Basın”, Atatürk Araştırma Merkezi Dergisi, 4, no. 11 .

Bolu Livası Salnamesi (1922). 1921-1922, Bolu: Bolu Hükümet Matbaas1.

Çı̆̆g, Ünsal (2007). “19. Yüzyılda Osmanlıda Gazetecilik Hareketleri: Takvim-i Vekayi'den Vilayet ve Özel Girişim Gazetelerine”, Türkiye’de Yerel Basın, Editör: Suat Gezgin, İstanbul: İstanbul Üniversitesi İletişim Fakültesi Yayınları.

Ersoy, Osman (1959). Türkiye’ye Matbaanın Girmesi ve Illk Basılan Eserler, Ankara: A.Ü. DTCF Kütüphanecilik Enstitüsü.

Gündüz, Uğur (2007). “Kurtuluş Savaşı'nda Yerel Basının Rolü’, Türkiye’de Yerel Basın, Editör Suat Sezgin, İstanbul: İstanbul Üniversitesi İletişim Fakültesi Yayınları..

Güner, Zekai (1998). “Millî Mücadele’de Türk Kamuoyunu Oluşturan Basın”, Erdem, 11, no. 31 .

Güz, Nurettin (1999). “Cumhuriyetin İlanına Basının Bakışı”, Selçuk İletişim, 1, no. 1.

İnuğur, M. Nuri (1993). Basın ve Yayın Tarihi, İstanbul: Der Yayınları.

Kılıç, Fahri (2019). "Millî Mücadele Döneminde Türkoğlu Gazetesi”, Yakın Dönem Türkiye Araştırmalarl, 36, (49-64).

Kilıç, Fahri -Murat Tarhan (2014). “Tanzimat'tan Cumhuriyet'e Bolu'da Eğitim Uygulamaları”, AIB̈̈̈ Sosyal Bilimler Enstitüsü Dergisi, 14/14, no. 3.

Kılıç, Sezen (2008). “Cumhuriyetin İlk Yıllarındaki Gelişmeleri Basının Yorumlayışı (19231926)", Atatürk Araştırma Merkezi Dergisi, 24, no. 70.

Kocabaşoğlu, Uygur (1991). “Tuna Vilayet Gazetesi”, OTAM (Ankara Üniversitesi Osmanlı Tarihi Arasttrma ve Uygulama Merkezi Dergisi), no. 2, (141-149).

Koloğlu, Orhan (1989). İlk gazete, İlk Polemik: Vekayi-i Misriye’nin Öyküsü ve Takvimi Vekayi ile Tartışması, Ankara: Çağdaş Gazeteciler Derneği.

Koloğlu, Orhan (1982). Takvim-i Vekayi: Türk Basınında 150. Yıl: 1831-1981, Ankara: Ankara Basım Sanayi.

Koloğlu, Orhan (1985). “Osmanlı Basını, İçeriği ve Rejimi”, Tanzimat'tan Cumhuriyete Türkiye Ansiklopedisi, hazırlayan Murat Belge-Fahri Aral, cilt I, İstanbul: İletişim Yayınları, 6893. 
Koloğlu, Orhan (1994). Osmanlı'dan Günümüze Türkiye'de Basın, İstanbul: İletişim Yayınları. Koloğlu, Orhan (1998). Osmanlı Basınının Doğuşu ve Blak Bey Ailesi, İstanbul: Müteferrika.

Korkmaz, Şerif (1999). “İbrahim Müteferrika ve İlk Türk Matbaası”, Dini Araştırmalar, cilt 2, no. 5, (Eylül Aralık), 285-297.

M. Besim (1339). "Halkçılık”, Milli Gaye, no. 6, (5 Şubat 1339).

Nalcıŏlu, Belkıs Ulusoy (2013). Osmanlı'da Muhalif Basının Doğuşu, İstanbul: Yeditepe.

Özkaya, Yücel (1985). "Milli Mücadele Başlangıcında Basın ve Mustafa Kemal Paşanın Basınla İlişkileri”, Atatürk Araştırma Merkezi Dergisi 1, no. 3.

Polat, Nazım H. (2002). “Türkiye'de Yerel Basının Gelişimine Kısa Bir Bakış”, TÜBAR, XII.

Tiken, Servet (2015). "Cenevre'de Bir Jön Türk Mizah Gazetesi: Tokmak”, A. Ü. Türkiyat Araştırmaları Enstitüsü Dergisi [TAED] 54, Erzurum 2015, 403-415.

Topuz, Hıfzı (1973). 100 Soruda Türk Basin Tarihi, İstanbul: Gerçek Yayınevi.

Tosun, Ramazan (2002). "Cumhuriyetin İlanında Kamuoyu”, Selçuk Üniversitesi Türkiyat Araştırmaları Dergisi, no. 12.

Tütengil, Cavit Orhan (1971). "Olaylar ve Görüşler”, Cumhuriyet.

Uçak Olcay - Erkal, Abdi (2019). “Osmanlı'dan Günümüze Türkiye'de Yerel Basının Gelişim Süreci”, Selçuk İletişim, 12 (1), 92-122.

Uçak, Olcay - Abdi Erkal ((2019). “Osmanlı'dan Günümüze Türkiye’de Yerel Basının Gelişim Süreci”, Selçuk İletişim, 12, no. 1.

Ulusoy, Belkıs (2004). “Milli Mücadele, Propaganda, Atatürk ve Basın”, İstanbul Üniversitesi İletişim Fakültesi Dergisi, no. 20.

Yazıcı, Nesimi (1983). Takvim-i Vekayi: Belgeler, Ankara: Gazi Üniversitesi Yayınları.

Yediyıldız, Mustafa Asım (1991). “İbrahim Müteferrika”, Vakıflar Dergisi, 22, 441-447. 
e-ISSN 2458-7672

https://dergipark.org.tr/tr/pub/jhf
Tarih ve Gelecek Dergisi, Aralık 2020, Cilt 6, Sayı 4 Journal of History and Future, December 2020, Volume 6, Issue 4

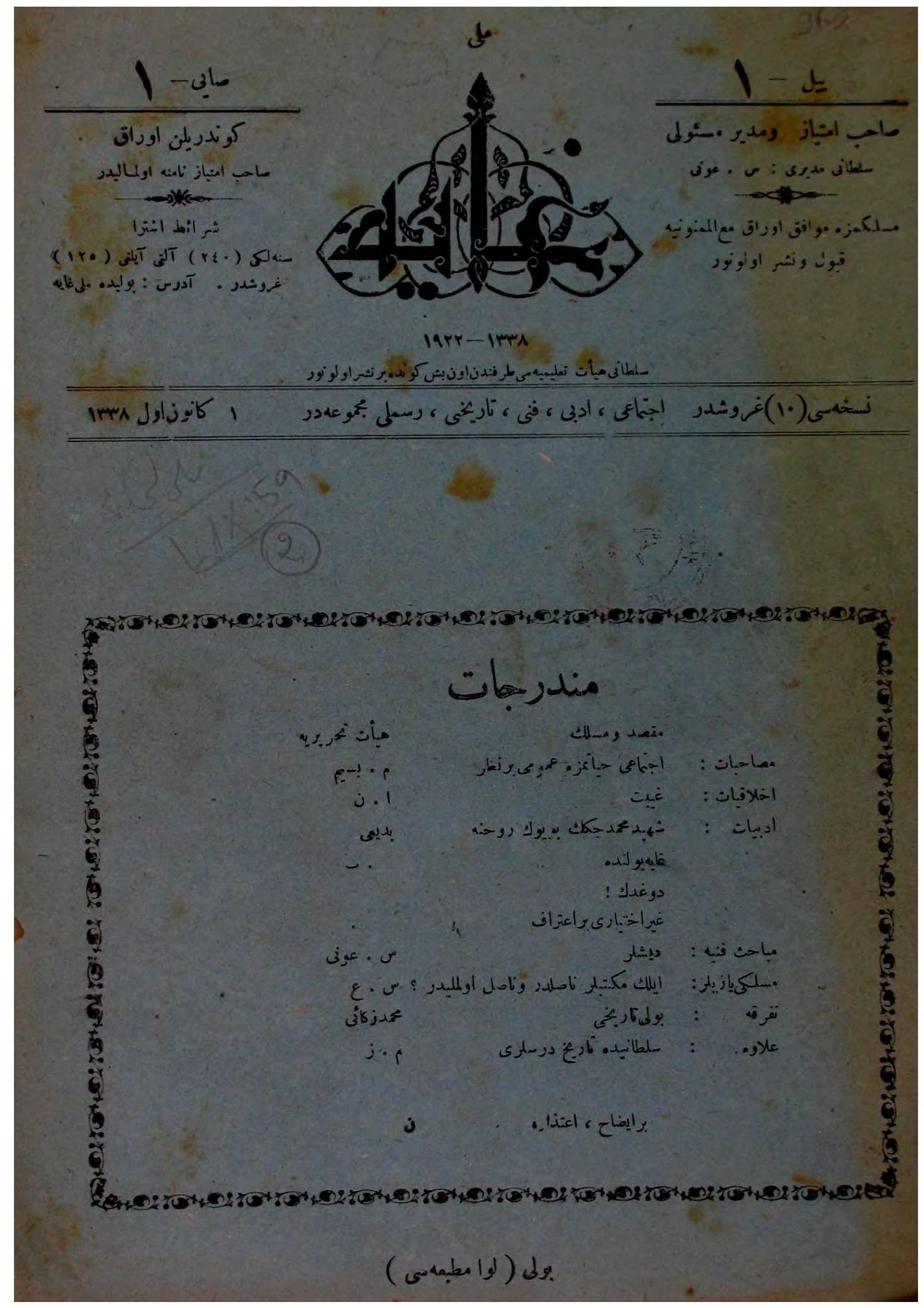

